手作業に勝るもではないが，Photo. 4 に示した実作業 の例についていえば, 1 台の装置で1日（8 時間）の王 接数は最高109個所であった。

\section{5. 結語}

著者等はガス圧接継手の品質向上と信頼性增大を目的 とする可搬式自動ガス圧接機を闒発し，太径鉄筋を対象 とする多くの実験を重ねて，王接条件と工程プログラム を設定し，さらに実地試験を経て，ようゃく実用の域に 達することが出来た，建設現場における鉄筋の自剑ガス 过接は本法を以て喍矢とするが，現在の装置は（D35

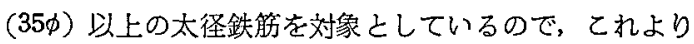
あ細いサイズの鉄筋への適用卆望まれている，そして， てれは同様な原理によって十分可能であり，工程と装置 の簡易化によって，さらに今後の発展を期待しうる分野 であある．本報告は，鉄筋の自動ガス圧接の実用化に一
応の成功を見た現段階において，その原理と方法および 装置について述べたものである，本装置の実用化には， 正接条件，正接工程プログラム等について多くの実験が 行われたので，それらの結果については続報において報 告したいと考えている.

䊏りに，本装置の実用化に当って，東亜王接株式会社 の協力を得たととを記して，謝意を表するむのである.

\section{文献}

1) A.B. Kinzel : Adams Lecture-Solid Phase Welding, Welding Journal, 1944, pp. 1124 1144

2) R.F. Tylecote: The Solid Phase Wilding of Metals, Edward Arnold, (1968), London.

3）橋本迲哉，田沿欣司：固相接合，本嘉，Vol. 41 (72)，No. 1, pp. 19 27

4) H.A. Mohamed \& J. Washburn : Mechnism of Solid State Pressure Welding, Welding J., 54-9 (1975) 302s $310 \mathrm{~s}$

\title{
チタンとアルミニゥムとの拡散溶接*
}

\author{
圓城敏男** 池内建二** 金井雅仁 ${ }^{* * *}$ 丸山敏治****
}

\section{Diffusion Welding of Titanium to Aluminum*}

\author{
by Toshio Enjyo**, Kenji Ikeuchi**, Masahito Kanai*** \\ and Toshiharu Maruyama****
}

\begin{abstract}
Diffusion welding of titanium to aluminum has been performed. It is an example of the welding between dissimilar metals which form brittle intermetallic compounds in the bonding interface.. In order to investigate the important factors which affect the mechanical properties of joint, the microstructure in the bonding zone was examined in detail with several metallographic methods, such as optical micrograph, Knoop hardness test, X-ray analysis and scanning electron micrograph. The results obtained are summarized as follows:
\end{abstract}

1. The joint strength increased with increasing welding temperature and time. The joints welded for more than $30 \mathrm{~min}$. at $600^{\circ} \mathrm{C}$ were fractured at aluminum base metals on the tensile strength test.

2. The interlayer which consisted of intermetallic compound $\mathrm{Al}_{3} \mathrm{Ti}$ was formed in the bonding interface. The thickness of this interlayer increased almost linearly with welding time. The increase in the thickness did not reduce the joint strength up to $10 \mu \mathrm{m}$ at least.

3. The oxide film on the faying surface of aluminum was considered to be the most important factor which affects the joint strength. That is, the joint strength did not increase sufficiently since the oxide film inhibited the formation of metallic bond between the base metals.

4. The formation of metallic bond between the base metals proceeded preferentially in the regions where the oxide film was broken by the micro-asperities on the faying surface of titanium.

\footnotetext{
*原稿受付 昭和51年 8 月 2 日 (昭和51年度春季全国大会にて発表)

**正 員大阪大学溶接工学研究所 Member, Welding Research Institute, Osaka University

****学 生 員 大阪大学大学院 Student Member, Faculty of Engineering, Osaka University(現 $r \equiv$ 名自工)

****学 生冒 大阪大学大学梡 Student Member, Faculty of Engineering, Osaka University
}

\section{1. 緒言}

拨散溶接は，母材を溶融することなく，接合界面での 原子の熱活性化㹡散を利用して被溶接物を接合しようと する方法で，従来の溶接法とは全く異なった原理に基づ 
くあのである．このため搪散溶接は，従来の溶接法では 困難よされてきた金属間あるいは部品間の溶接への適用 が検討されているが，その1つとして異種金属間の溶接 を挙げるととができる゙,2).

拡散溶接法による異種金属間の溶接についてはすでに 種々の報告があるが，母材破断を生ずる上うな十分な継 手強さを得るに至ってないすのが多い，とくに，接合界 面に脆い金属間化合物を形成する異種金属間，例えがチ タンと軟鐥1,3,4)，アルミニウム之軟鋼1,5)，アルミニウ ムと銅】などでは得られる継手強さは母材に比べて非常 儿低い場合が多い．乙れらの継手の機械的性質の改善を 図るためには，接合界面にどの上うな金属間化合物がい かなる状態で形成されまたそれらが継手強さにどのよ うな影響をおよぼすがついての知見が必要不何欠之考 えられる.

筆者らはすでにチタン合金 $(15 \% \mathrm{Mo}, 5 \% \mathrm{Zr}$ を含 む）之軟鋼との継手の接合部に形成される化合物層の微 細構造を明らかにし，継手強さと化合物首之の関係につ いて検討を加えてきだ). 本研究においては、金属間化 合物を形成する異種金属継手の1例として，実用的に屯 化学工業の分野での応用が期待されるチタンとアルミニ ウムとの拡散溶接を行ない, 継手強さに影響をおよぼす 諸因子について検討を加えた。

\section{2. 実 験 方 法}

\section{1 供試材}

本研究において用いられた母材は工業用純チタンとア ルミニウムであり，その化学成分を Table 1 亿示す. 母材の引張強さは, チタンは $39 \mathrm{~kg} / \mathrm{mm}^{2}$, アルミニウ ムは $6 \sim 8 \mathrm{~kg} / \mathrm{mm}^{2}$ であった。試片の形状はチタン，ア ルミニウムとあに直径 $20 \mathrm{~mm}$, 長さ $37 \mathrm{~mm}$ の丸棒之 した.これらの丸棒の両端面は，平滑さ之丸棒軸化対す る直交性を満足するために，故盤加工によって $\nabla \nabla \nabla$ 程度に仕上げられている. この端面を接合面として溶接 を行なった。

Table 1 Chemical compositions.

\begin{tabular}{|l|c|c|c|c|c|}
\hline \multirow{2}{*}{ Specimen } & \multicolumn{4}{|c|}{ Chemical Composition $(w t \%)$} \\
\cline { 2 - 6 } & $\mathrm{Fe}$ & $\mathrm{N}$ & 0 & $\mathrm{H}$ & $\mathrm{Ti}$ \\
\hline Titanium & 0.038 & 0.0030 & 0.065 & 0.0028 & Bal. \\
\hline
\end{tabular}

\begin{tabular}{|l|c|c|c|c|c|}
\hline \multirow{2}{*}{ Specimen } & \multicolumn{5}{|c|}{ Chemical Composition (wt \%) } \\
\cline { 2 - 6 } & $\mathrm{Cu}$ & $\mathrm{Fe}$ & $\mathrm{Si}$ & $\mathrm{Mg}$ & $\mathrm{Al}$ \\
\hline Aluminum & 0.032 & 0.20 & 0.08 & 0.02 & $\mathrm{Bcl}$ \\
\hline
\end{tabular}

接合表面の凹凸を触針式粗さ計によって調べた結果を Fig. 1 に示す. 図のように, 凹凸の最大高さはチタン, アルミニウムのいずれにおいても約 $1 \mu \mathrm{m}$ 程度である
が凹凸の周期はチタンで

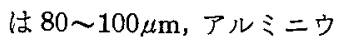
ムでは $50 \mu \mathrm{m}$ 程度である.

\section{2 溶接方法および測 定方法}

本研究に批いては，应散 溶接は Fig. 2 亿示す装置 を用いて以下に記す手順で 行なったまず，接合面の 前処理としてアセトンによ る脱脂洗浄を溶接直前飞行 なった，つぎに，接合面を つき合わせて試片を接合室 内の加正棒の間仅取りつけ たあと，接合室内を排気し

\section{a) TITANIUM}

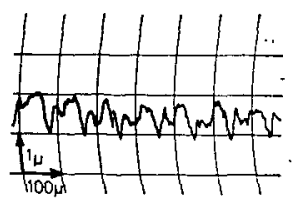

b) ALUMI NUM

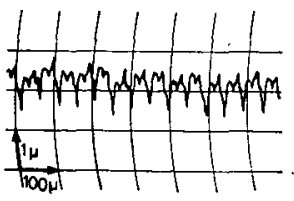

Fig. 1 Roughness of the faying surfaces.
た. 接合室内の点 空度が $\leq 1 \times 10^{-4}$ $\mathrm{mmHg}$ に達した のを確認後，接合 部を所定の温度に 加熱した.

乙の際，加熱法 として Fig. $2 に$ 示すように高周波 誘導加熱法を用い ているために，接 合部が不均一に加 热されるおそれが ある.すなわち， 1つは高周波の表 皮効果のため試

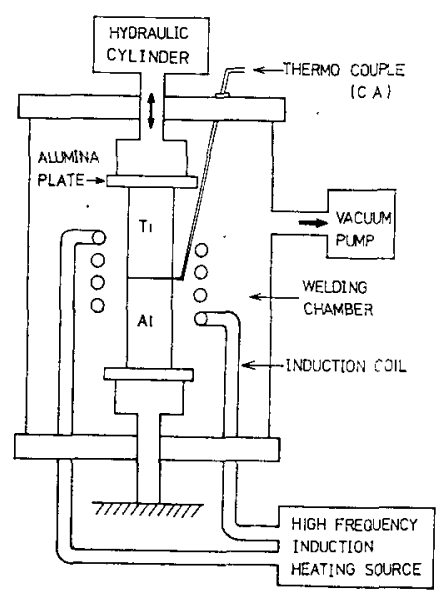

Fig. 2 Schematic diagram of diffusion welding apparatus.
片表面のみがとくに加熱されやすいとと，また1つはチ タンとアルミニウムとの間の電気抵抗や熱伝導度, 熱镕 嘼の差によって雨金属間の加熱されやすさに差があるた め，接合部の半径方向执よび軸方向に温度差が生じる可 能性がある。乙のため，Fig. 3 飞示すように，チタン とアルミニウムの雨試片の表面に拈いて接合界面から $1 \mathrm{~mm}, 3 \mathrm{~mm}$ はなれた点, および試片表面と中心部に 熱電対をパーカッション溶接し，各点の温度上昇特性を 調べた. その結果, Fig. 3 亿示すように加熱開始後約 2 分間で接合部の温度は試片軸方向, 半径方向之もにほ ぼ均一になっているととが明らかとなった。

この結果より, 接合部の温度はチタン試片表面上の接 合界面から $1 \mathrm{~mm}$ はなれた点にパーカッション溶接さ れた C-A 熱電対によって測定し，接合面に対する加生 は加熱開始後 2 分間経てから行なうことにした．溶接終 

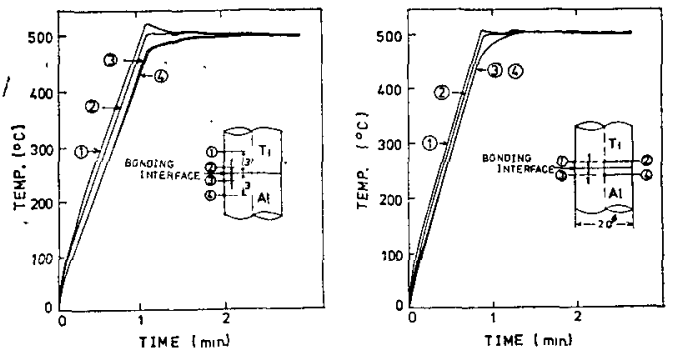

Fig. 3 Variation of temperature with heating time at each point (1), (2), (3) and (4) indicated in the figure.

了後, 継手は $250^{\circ} \mathrm{C}$ まで真空中で冷却したあと大気中 に取り出した。

測定方法の詳細を以下にま之める．顕摧鏡組織钼祭の ための腐食液は Kroll 氏液を用いた. X 線解析は $\mathrm{Cu} の$ $\mathrm{K} \alpha$ 線を用いて行なった．走查型電子顕微鏡 (SEM) 観 察は日立製作所製 HSM-2B 型を用い，加速䉓圧 $20 \mathrm{kV}$ で行なった．硬さ測定は Knoop 微小硬さ計を用いて行 なった．引張試験は，インストロン型引張試験機を用い て, 変形速度 $1 \mathrm{~mm} / \mathrm{min}$ で行なった. 引張試験片の形 状は Fig. 4 に示すとおりである.

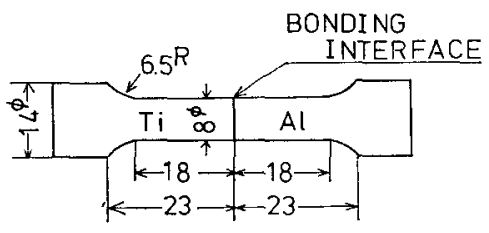

Fig. 4 Specimen for tensile test.

\section{3. 実験結果および考察}

チタンとアルミニウムとの異種金属継手の強度と溶接 温度, 時間および王力との関係を Fig. 5 亿示す. 一般 亿接合界面に脆い金属間化合物を形成する翼喠金属間の 継手に扔いては, 継手強度は限られた溶接温度, 時間の 簌囲内で極大值をとるととが多い1,3,4)。 しかし，Fig. 5 に示すように，チタンとアルミニウムとの継手の場合 は，本実験で行なった条件範目内では継手強さは溶接条 件が高温かつ長時間であるほど高くなり，600ㄷ C゙30分 以上で溶接された継手はすべて母材破断した．溶接圧力 の継手強さにおよぼす影響は，Fig. 5 亿示すように，溶 接温度が $500^{\circ} \mathrm{C}$ の場合は顕著で压力の高い方が強度は 高かった. また，図示してはいないが，溶接温度，時間 がそれぞれ $450^{\circ} \mathrm{C}$ および 30 分の場合は，溶接压力が $0.5 \mathrm{~kg} / \mathrm{mm}^{2}$ では $1.3 \mathrm{~kg} / \mathrm{mm}^{2}$ 程度の強度が得られた が，それ以下の圧力では強度は非常に低かった。 しか し, 溶接温度が $550^{\circ} \mathrm{C}$ の場合は, 本研究の箸柬内（压

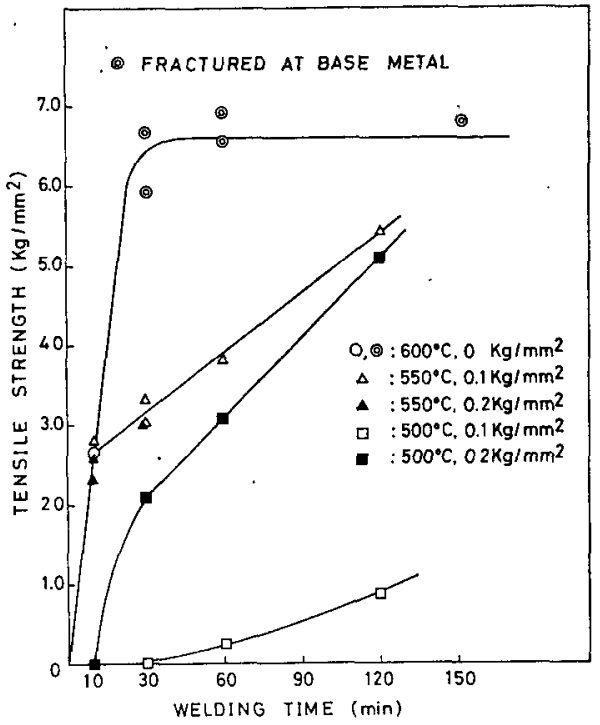

Fig. 5 Effect of welding time on the joint strength at various welding tem. perature and pressure.

力 $\left.=0.1 \sim 0.2 \mathrm{~kg} / \mathrm{mm}^{2}\right)$ では継手強さに対する溶接圧 力の影㗽はほとんで認められなかった。 なお，溶接温度 が $600^{\circ} \mathrm{C}$ の場合はアルミニウム母材の軟化が著しいた め, 溶接圧力は加えなかった．以上のように，溶接压力 の継手強さにおよぼす影響は，溶接温度が低温では顕著 であるが，高温になると小さくなる。

拡散溶接の特長の 1 つとして, 溶接変泟量の小さいて 之があげられている1,2,7). Fig. 6 亿本研究で得られた 継手の溶接変形量を示す. Fig. 5 上 Fig. 6 亿示すよう に, 溶接温度と王力が $600^{\circ} \mathrm{C}, 0 \mathrm{~kg} / \mathrm{mm}^{2}$ の場合には非 常に小さい変形量でしかも母材破断する継手強さを得る ととができた。

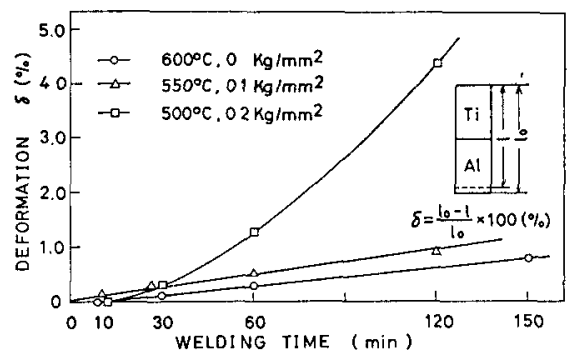

Fig. 6 Effect of welding/time on welding deformation at : various welding temperature and pressure.

継手強さが溶接条件によって Fig. 5 に示すような恋化 をする理由を明ら汃化するため接合部の組織観察を行 なった. Photo. 1 亿接合部の光学顕微鏡写真を示す. 


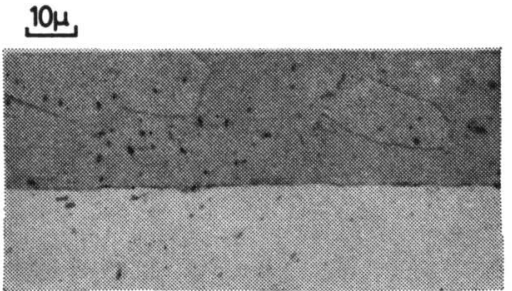

$\mathrm{Ti}$

Al

$500^{\circ} \mathrm{C}, 30 \mathrm{~min} ., 0.3 \mathrm{Kg} / \mathrm{mm}^{2}$

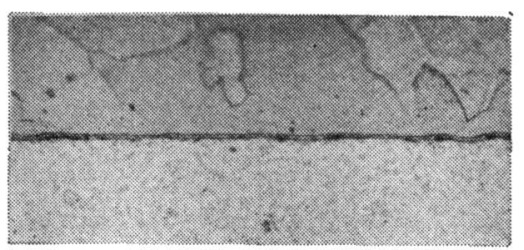

$\mathrm{Ti}$

Al

$550^{\circ} \mathrm{C}, 30 \mathrm{~min} .0 .1 \mathrm{Kg} / \mathrm{mm}^{2}$

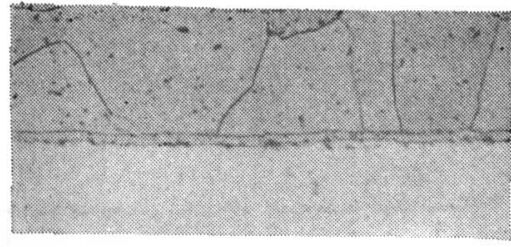

$\mathrm{Ti}$

Al

$600^{\circ} \mathrm{C}, 60 \mathrm{~min} ., 0 \mathrm{~kg} / \mathrm{mm}^{2}$

Photo. 1 Microstructures of bonding zones between titanium and aluminum.

写真のように, チタンとアルミニウムの母材には組織变 化はほとんど認められないが，接合界面近傍には金属間 化合物の形成されていると思われる層が観察される. この層の巾は, Photo. 1 に示すように, 溶接条件が高 温かつ長時間であるほど広くなった。接合部の Knoop 硬さ分布曲線を Fig. 7 亿示すが, 接合界面近傍の層の 硬さは両母材に比べて著しく高い，乙のととは，乙の層 が金属間化合物からなるととを示唆している．との層を さらに詳細に検討するために, 走査型電子顕微鏡 (SEM) による組織観察を行なった結果を Photo. 2 亿示す.

Photo. 2 には, 非分散型 X 線分析器によって測定した チタンとアルミニウムの特性 $\mathrm{X}$ 線 $(\mathrm{K} \alpha)$ の強度分布曲 線を同時に示す. Photo. 2 のように, 接合界面近傍に 形成された層の中ではチタンとアルミニウムの分布曲線 の勾配がともに低くなり，乙の層がチタンとアルミニウ ムとの金属間化合物からなることが示唆される.

この化合物層に形成されている金属間化合物を同定す るためにX線解析を行なった結果を Fig. 8 亿示す. X線 解析は引張試験によって接合部で破断した継手の破面か らの回折線によって行なった. 用いた X 線は $\mathrm{Cu} の \mathrm{~K} \alpha$ 線である. Fig. 8 に示すように, チタンとアルミニウム の回折線以外には $\mathrm{Al}_{3} \mathrm{Ti}$ の回折線のみしか認められな

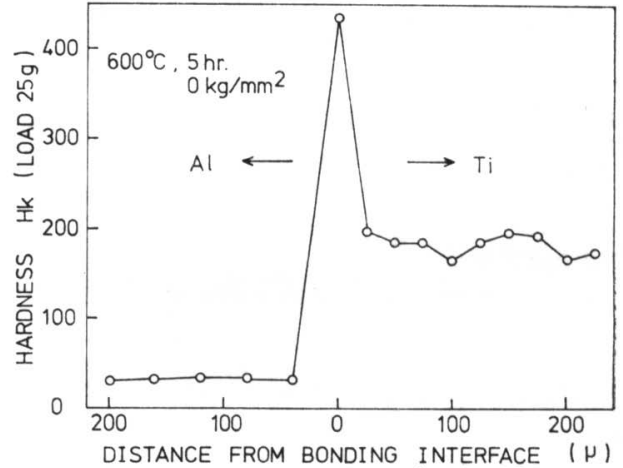

Fig. 7 Distribution of Knoop hardness numbers in bonding zone. The welding temperature, time and pressure were $600^{\circ} \mathrm{C}$, $5 \mathrm{hr}$. and $0 \mathrm{Kg} / \mathrm{mm}^{2}$, respectively.

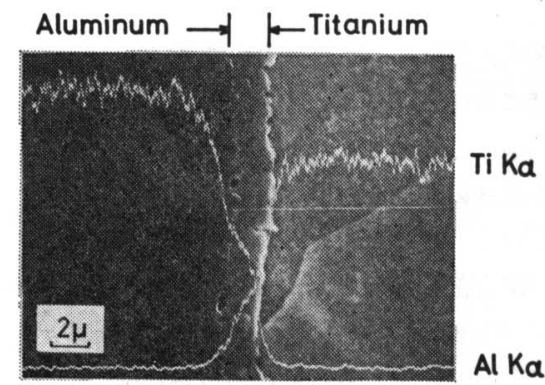

Photo. 2 Scanning electron micrograph of bonding zone and intensities of characteristic X-ray of each element analyzed along the white straight line. The welding temperature, time and pressure were $600^{\circ} \mathrm{C}, 1 \mathrm{hr}$. and $0 \mathrm{Kg} / \mathrm{mm}^{2}$, respectively.

い. チタンとアルミニウムの間に形成される金属間化合 物としては, 平衡状態図8 では $\mathrm{Al}_{3} \mathrm{Ti}$ と $\mathrm{AlTi}$ が挙げ られているが, このように拡散溶接においては AlTi の 形成は認められない。 このととより, Photo 1, 2 亿示 す化合物層は $\mathrm{Al}_{3} \mathrm{Ti}$ からなるむのと考えられる. との 結果は, van Loo と Rieck ${ }^{9}$ 亿よって行なわれた長時 間の拡散実験の結果とも一致している.

接合界面に脆い化合物層が形成された場合, 化合物層 の巾が広くなるほど継手強さの低下が著しくなると従来 よりいわれている. 実際, チタンとアルミニウムとの拡 散溶接継手の強さは, 化合物層の巾が $4 \sim 6 \mu \mathrm{m}$ 程度に なると低下するという報告がなされている4). 本研究に おいても，化合物層の継手強さに対する影響を調べるた めに, $600^{\circ} \mathrm{C}$ で長時間保持して溶接を行ない, 化合物層 の巾を大きく生長させた継手の強度を調べた. その結 果, Fig. 9 亿示すように化合物層の巾を最高 $10 \mu \mathrm{m}$ 程 
度まで生長させたが継手強さの低下はほとんどな く，継手は乎材皮断した．とのととは，金属間化 合物層の形成による継手強さの低下はほとんどな いととを意味している.

なお，一般仅反応拡散過程において金属間化合 物層が生長する埸合，化合物層の巾は時間の平方 根に比例して増加するといわ礼ているが10), Fig. 9 に示すようにチタンとアルミニウムでは化合物 層の巾は時間にほぼ比例して增加している。この 結果は, van Loo と Rieck4)によって行なわれ たより長時間の拡散害験の結果とむ一致している が, 金属間化合物尿の生長過程についてはさらに 詳細な検討を加える必要があると思われる.

以上の上うに，チタンとアルミニウムの継手強 さの向上を妨げる因子は化合物層の形成以外にあ るあのと考えられる，従来より，アルミニウムの 拡散溶接においては，アルミニウムの接合面上の 酸化皮膜が接合界面での金属結合の形成を阻害 し，継手強さの向上を妨げているのではないかと いわれている.とのととを確かめるため，まず酸 化皮膜が接合部のどの部分飞存在するかを調べ た. 直径 $20 \mu \mathrm{m}$ のタングステン細線をマーカー

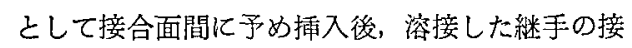
合部の組織を Photo. 3 に示す. 写真のように, マーカーは化合物層に接した状態でアルミニウム 中に埋めてまれている.とのことは，チタンとア ルミニウムの元々の接合界面は化合物層とアルミニウム との境界㑑当するてとを示している.なぜなら, 溶接 温度 $600^{\circ} \mathrm{C}$ ではアルミニウムばチタンに比べて非常に 軟化するため，マーカーは溶接压力によって溶接開始後 值ちにアルミニウム中に埋め込まれると考えられるから である．すなわち、アルミニウムの酸化皮膜は化合物層 とアルミニウムとの境界存在すると考元られる.

アルミニウムの酸化皮膜の継手強さにおよぼす影響を 検討するために，接合部で破断した継手の破断部縃断面 の組織を Photo. 4, 5 に示す. Photo. 4 に示すように, 継手強さの低い場合は破断はアルミニウムと化合物層之 の境界で起こっている. また，母材破断に近い継手強さ の場合も, Photo. 5 亿示すように継手は主としてアル ミニウムと化合物層との境界で破断している. 前記の上 うに酸化皮膜はアルミニウムと化合物層との境界に存在 すると考えられるので,・とのような破断状態は酸化皮膜 が継手強さの向上を妨げるという考え方を支持するすの である.

また，Photo. 5 に示すように母材破断に近い強さを むつ継手の破断部に打いては, チタン側にアルミニウム

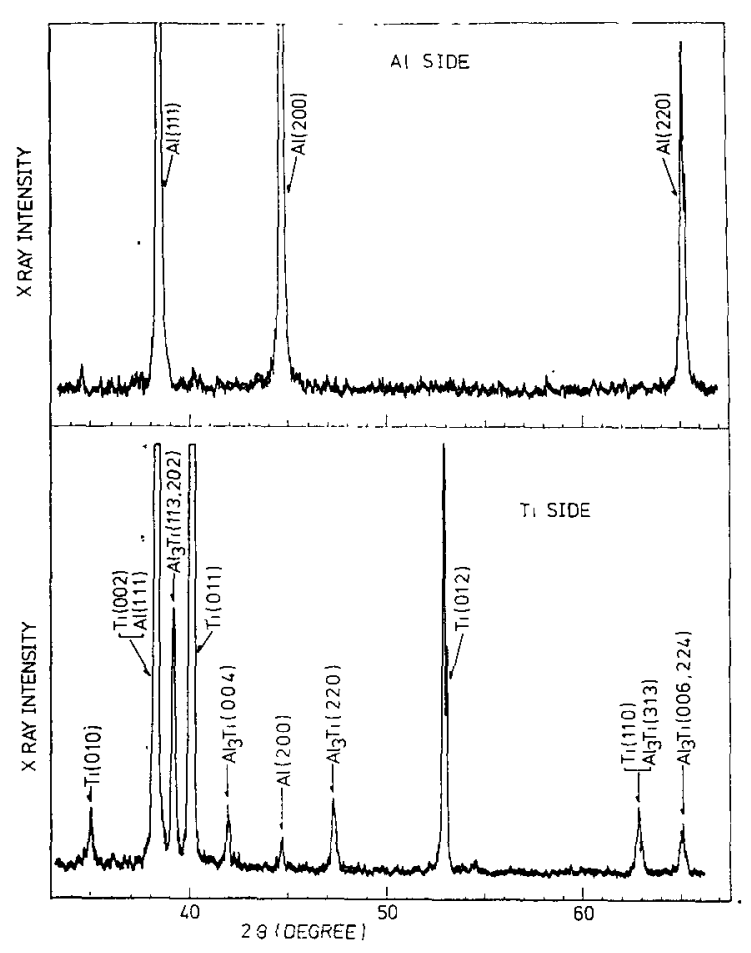

Fig. 8 X-ray diffraction patterns from the fractured surfaces of the joint fractured at the bonding zone. The welding temperature, time and pressure were $500^{\circ} \mathrm{C}, 2 \mathrm{hr}$. and $0.2 \mathrm{Kg} / \mathrm{mm}^{2}$, respectively.

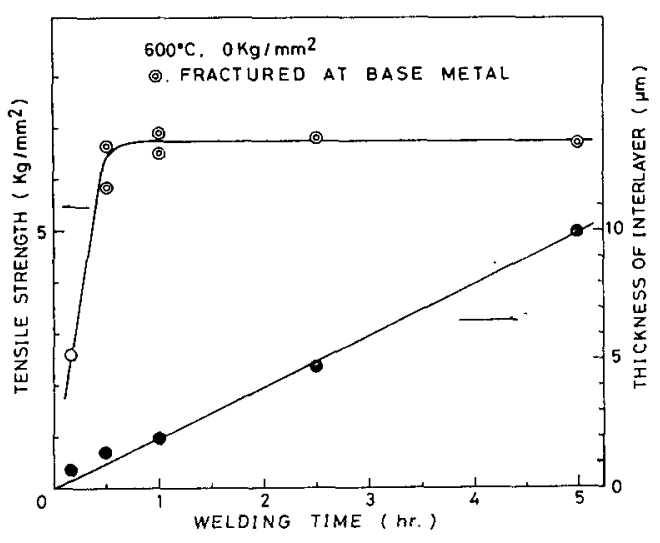

Fig. 9 The relation between the joint strength and the thickness of the interlayer consisted of intermetallic compound. The welding temperature and pressure were $600^{\circ} \mathrm{C}$ and $0 \mathrm{Kg} / \mathrm{mm}^{2}$, respectively.

が付着し、アルミニウム中で破断が起こったと考えられ る領域が周期的に形成されている. その周期の間隔は約 $80 \mu \mathrm{m}$ である. このアルミニウム中で破断が起とってい 


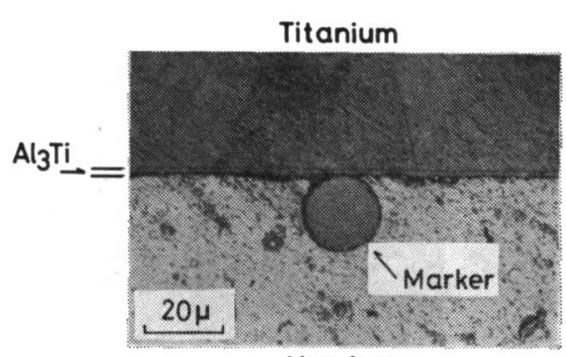

Aluminum

Photo. 3 Microstructure of bonding zone with a marker of tungsten wire. The welding temperature, time and pressure were $600^{\circ} \mathrm{C}, 1 \mathrm{hr}$. and $0 \mathrm{Kg} / \mathrm{mm}^{2}$, respectively.

\section{Titanium}

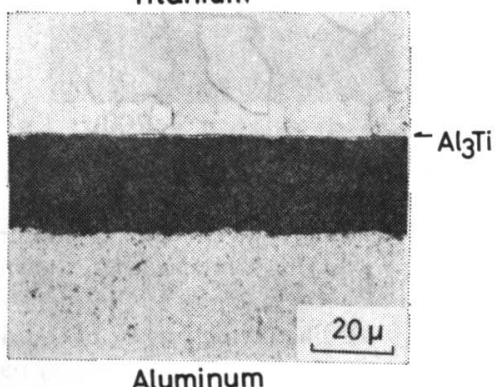

Photo. 4 Cross sectional microstructure of the fractured zone obtained from the joint whose strength was much lower than that of aluminum base metal. The welding temperature, time and pressure were $600^{\circ} \mathrm{C}, 10 \mathrm{~min}$. and $0 \mathrm{Kg} / \mathrm{mm}^{2}$, respectively.

る領域ではチタンとアルミニウムとの間に金属結合の形 成が優先的に進行したものと考えられる.

このような金属結合の形成が優先的に進行する領域が どのようにして形成されていくかを調べるために, SEM による破面観察を行なった. Photo. 6 に母材破断に近 い強度を示した継手の破面を示す. Photo. 6 a ）には, 非分散型 $\mathrm{X}$ 線分析器によって調べたチタン側破面におけ るアルミニウムの特性 $\mathrm{X}$ 線の強度分布曲線をも示す. 写 真のように, チタン側, アルミニウム側いずれの破面に おいても同心円状の白い模様が観察され, しかむチタン 側破面におけるアルミニウムの特性 X 線の強度は同心円 状の模様の部分で非常に高くなっている．乙の同心円状 の模様の間隔は約 $80 \mu \mathrm{m}$ であり, Photo. 5 に示したチ タン側破面にアルミニウムの付着した部分の間隔とほぼ 一致している. また, この間隔は Fig. 1 亿示した粗さ 試験機によって調べたチタン接合表面の凹凸の周期とも a)

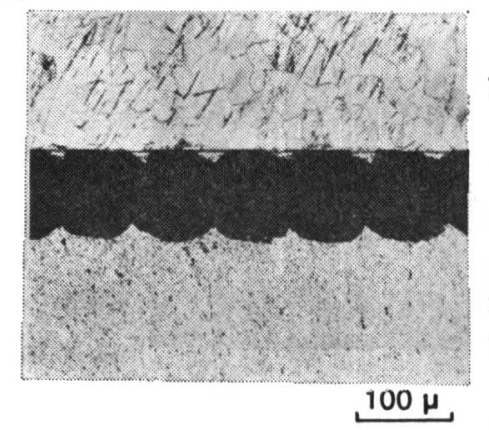

Titanium

b)

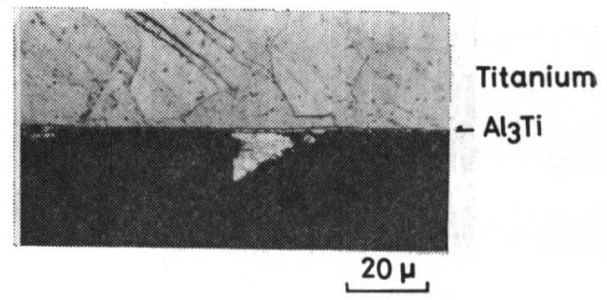

Photo. 5 Cross sectional microstructures of the fractured zone obtained from the joint whose strength was slightly lower than that of aluminum base metal. The welding temperature, time and pressure were $550^{\circ} \mathrm{C}, 2 \mathrm{hr}$. and $0.1 \mathrm{Kg} / \mathrm{mm}^{2}$, respectively.

ほぼ一致している. このととは, Photo. 6 亿示した同 心円状の模様は Photo. 5 に示したチタン破面に了ルミ ニウムの付着した領域に相当しており, しかもその領域 はチタン接合表面の凹凸に沿って形成されることを示し ている.すなわち，チタンとアルミニウムとの間の金属 結合の形成は，チタン接合表面の凹凸に沿って優先的に 進行することを示している，そして凸部は凹部よりもア ルミニウムとの機械的接触が容易なととを考慮すれば, チタン接合面の凸部でアルミニウムの酸化皮膜が破壊さ れ，そこから金属結合が優先的に形成されていくと考元 られる.

てのととを確めるために, チタンまたはアルミニウム の接合面の一方のみを 800 番のエメリ一紙によって研摩 した後溶接した継手のチタン側破面を Photo. 7 亿示す. 継手の溶接条件は, Photo 5, 6 亿示す継手のそれ之同一 にした. また， 800 番のエメリ一紙を選んだのは，その 研摩後の表面粗さが触針式粗さ計による測定の結果, 旋 盤加工仕上げのそれとほぼ同程度であったからである。

Photo. 7 a) の上うに, チタン接合面をエメリ一研摩 した継手の破面においては同心円状の模様は観察されな い.しかし、アルミニウムの接合面のみをエメリ一研摩 した場合は, Photo. 7 b ）に示すように同心円状に了 
a) Titanium side

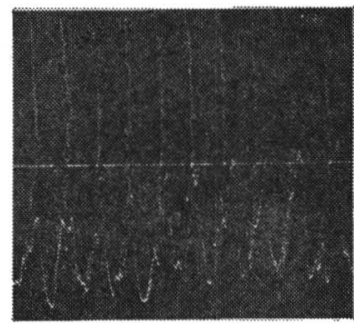

$\underline{200 \mu}$

\section{b) Aluminum side}

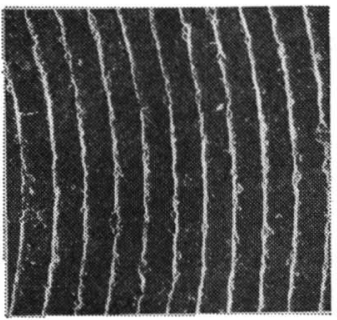

$200 \mu$

Photo. 6 Scanning electron micrographs of the fractured surfaces whose cross sectional microstructures are shown in Photo. 5. The intensity of characteristic X-ray of aluminum analyzed along the white straight line is shown in a).

ルミニウムの付着した領域が観察される．とのことはチ タン接合面の凸部に沿って金属結合の形成が優先的に進 行することを裹づけるあのである.

以上の上うに, チタンとアルミニウムとの拡散溶接に おいては, アルミニウム接合面上の酸化皮膜のために継 手強さの向上が妨げられること, また接合界面での金属 結合の形成はチタン接合面上の凹凸によって酸化皮膜の 破壊された領域から優先的に進行するととが明らかとな った.

\section{4. 結言}

本研究においては，金属間化合物を形成する異種金属 間継手の 1 例として，化学工業分野での適用が期待され るチタンとアルミニウムとの継手の拡散溶接過程につい て調べた。本研究で行なった溶接条件は, 溶接温度は $450 \sim 600^{\circ} \mathrm{C}$, 溶接時間は10 300分, 溶接圧力は $0 \sim 0.5$ $\mathrm{kg} / \mathrm{mm}^{2}$, 接合室内の真空度は $10^{-4} \mathrm{mmHg}$ 台である。 光学顕微鏡, $\mathrm{X}$ 線解析および走査電顕などを用いて接合 部の金属組織あるいは引張試験後の破断部の金属組織の 詳細な観察を行ない，継手強さに影響をおよぼす因子お a)

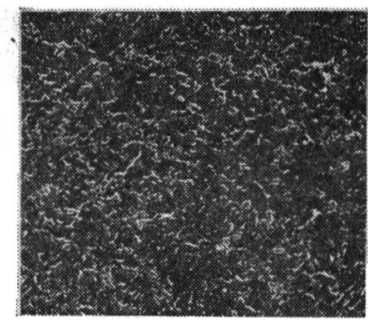

$200 \mu$

b)

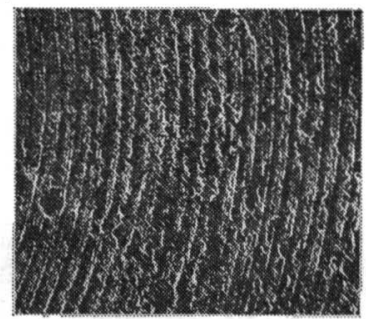

$200 \mu$

Photo. 7 Effect of polishing of the faying surface on the titanium fractured surface. The welding condition was the same as that shown in Photo. 6.

a) The faying surface of titanium was polished with emery paper (No. 800) prior to welding.

b) The faying surface of aluminum was polished in the same manner.

よび接合界面における金属結合の形成過程に関して検討 を加えた. その結果, 以下に記す点が判明した.

1）チタンとアルミニウムとの拡散溶接継手の強さ は, 本研究の範囲内では溶接条件が高温かつ長時間であ るほど高くなり, $600^{\circ} \mathrm{C}$ で30分以上保持して溶接した場 合は継手は母材破断する. また, 溶接圧力の継手強さに 対する影響は溶接温度が低いほど顕著であり, 圧力の大 きい方が強さは高い.

2）接合界面には $\mathrm{Al}_{3} \mathrm{Ti}$ 加らなる金属間化合物層が 形成され，その層の巾は溶接時間にほぼ比例して増加す る. この金属間化合物層による継手強度の低下は, 層の 巾が $10 \mu \mathrm{m}$ 以内では認められない.

3）チタンとアルミニウムとの継手強さの向上を妨げ る因子はアルミニウムの接合面の酸化皮膜之考えられ る. すなわち，アルミニウムの接合面の酸化皮膜のため 亿接合界面での金属結合の形成が阻害され，継手強さが 十分に向上しないあのと考えられる.

4）接合界面での金属結合の形成は，チタンの接合面 の凸部によってアルミニウムの酸化皮膜の破買された領 域から優先的に進行していく. 


\section{参考 献}

1) N.F. Kazakov; Diffuzionaya Svarka Vakuume, Mashionostroyniye, (1968).

2) M.M. Schwartz; Modern Metal Joining Techniques, John Wiley \& Sons, (1969), 370.

3) Y. Arata, K. Terai, S. Matuda, H. Nagai and T. Yamada; Diffusion Welding of Titanium to Mild Steel, Trans. JWS, 4-1 (1973), 96-103.

4) G.K. Kharchenko; Problems in the Diffusion Welding of Dissimilar Metals (Reviews of Published Works), Avt. Svarka, 2-4 (1969), 29-32.

5) N. Iwamoto, M. Yoshida, S. Tabata, T. Takeuchi and M. Makino; Diffusion Welding of Mild Steel to Aluminium, Trans. JWRI, 4-2 (1975), 67-70.
6）国城男，池内建二，敛田孝道，金井雅化，荒田吉明：Ti-15\%

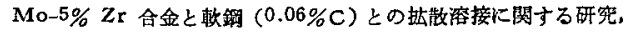
高温学会婄, 1-3 (1976)，36-48

7) R.F. Tylecote; The Solid Phase Welding of Metals, Edward Arnold, (1968), 301.

8) M. Hansen; Constitution of Binary Alloys, McGraw Hill, (1958), 139.

9) F.J.J. van Loo and G.D. Rieck; Diffusion in the Titanium-Aluminium System-I. Interdiffusion between Solid Al and Ti or Ti-Al Alloys, Acta Met. 21-1 (1973), 61-71.

10) S. Tsuji ; On the Determination of Diffusion Coefficients and the Estimation of the Rate Constants of Phase Interface Moving in a Multi-Phase Interdiffusion, Trans. JIM, 14-5 (1973), 377-381.

\title{
各種溶接割れ試験法の相関性について*
}

\author{
桐原誠信** 小沼勉** 渡辺潔** \\ Correlation for Method of Various Weld Cracking* \\ by Seishin Kirihara**, Tsutomu Onuma** and Kiyoshi Watanabe**
}

The relationships between various weld crack test methods were discussed at the 9 th Commission meeting of I.I.W. This article evaluates crack determination methods for slit groove tests, H-type restraint cracking tests, TRC tests, RRC tests and Implant tests, and discusses the intensity of restraint and restraint stress influencing crack prevention preheating temperatures. Finally the relationships between various test methods are clarified concerning cracks caused in first layer. The results are as follows:

(1) The dependence of delayed cracks on colling speed (preheating), intensity of restraint, restraint stress and stress concentration will be explained using $80 \mathrm{~kg} / \mathrm{mm}^{2}$ high-strength steel.

(2) A nomograph was made up to clarify the relationships between the various test methods by relating the crack prevention preheating temperatures to critical restraint stress and critical intensity of stress in the first layer of $80 \mathrm{~kg} / \mathrm{mm}^{2}$ high-strength steel.

1. 緒

言

溶接部の割れ試験法については IIW，第IX 委員会で 各種試験の相関関係について討議されている. 一方日本 国内に抬いても日本鋼構造協会（JSSC）の研究班に上 って研究が行なわれている.そこで本研究はてれらと平 行してスリット形栻験片, H形試験片1), RRC 試験,

TRC 試験1，およびインプラント試験を行い，割れ防 止予熱温度之拘束度および拘束応力との関係を明らかに し，初屏溶接部について各種試験法の相関関係について 検討を行なった.

\footnotetext{
*原稿受付 昭和51年 5 月 31 日（昭和50年度春全国大会にて発表）

**正員 KK日立製作所, 日立研究所, Member, Hitachi Research Laboratory, Hitachi, Ltd.
}

\section{2. 実験}

\section{1 供試料}

供試母材は $80 \mathrm{~kg} / \mathrm{mm}^{2}$ 高張力鋼を用いた。溶接棒は 低水素系被覆アーク溶接棒 (AWS, E11016G 相当) $4 \phi$ を用いた。

Table 1 亿供試材の化学組成之機械的性質を示す.

\section{2 試験溶接}

溶接は下向で Table 2 に示す条件で行なっだ．溶接 棒の乾燥は $350^{\circ} \mathrm{C} て ゙ 1$ 時間以上行なった。また予熱は $\mathrm{H}$ 形試験片，スリット形試験片およびインプラント試 験の母板は電気炖で所定の温度以上亿加熱し, 電気炬よ り取り出し所定温度に冷却するのをまって行なった。一 方 RRC および TRC 試験片は溶接開先を狭み板厚の 6 